\title{
Perspective \\ Licensed Anti-Microbial Drugs Logical for Clinical Trials against Pathogens Currently Suspected in Alzheimer's Disease
}

\author{
Leslie C. Norins
}

check for updates

Citation: Norins, L.C. Licensed Anti-Microbial Drugs Logical for Clinical Trials against Pathogens Currently Suspected in Alzheimer's Disease. Antibiotics 2021, 10, 327. https://doi.org/10.3390/ antibiotics 10030327

Academic Editor: Nicholas Dixon

Received: 28 January 2021

Accepted: 18 March 2021

Published: 20 March 2021

Publisher's Note: MDPI stays neutral with regard to jurisdictional claims in published maps and institutional affiliations.

Copyright: (C) 2021 by the author. Licensee MDPI, Basel, Switzerland. This article is an open access article distributed under the terms and conditions of the Creative Commons Attribution (CC BY) license (https:// creativecommons.org/licenses/by/ $4.0 /)$.
Alzheimer's Germ Quest, 4301 Gulfshore Blvd. N., Suite 1404, Naples, FL 34103, USA; leslie.norins@alzgerm.org; Tel.: +1-239-649-1346

\begin{abstract}
There is now considerable evidence that several infectious agents (viruses, bacteria, or parasites) may play a contributing role in the development of Alzheimer's disease (AD). The six primary suspects are herpes viruses, spirochetal bacteria, Chlamydia pneumoniae, Porphyromonas gingivalis, mycobacteria, and toxoplasma parasites. Also, some of the antimicrobial and antiviral agents that are used to treat them have shown promise for AD interventions. I describe this evidence and assert it is now time to accelerate clinical trials of these existing drugs, already federally approved, to determine if such treatments can delay, halt, or reverse AD.
\end{abstract}

Keywords: Alzheimer's disease; dementia; beta-amyloid; germ theory; drug development; clinical trials; herpes; spirochetes; Chlamydia pneumoniae; Porphyromonas gingivalis; toxoplasma; mycobacteria

\section{Introduction}

It is estimated that 44 million people worldwide have Alzheimer's disease (AD) or a related form of dementia. In the United States alone, nearly 6 million people have a diagnosis of AD [1]. Furthermore, since the world faces a dramatically increasing population of individuals aged 60 years or older, the number of AD and dementia diagnoses will only continue to grow. Thus, AD represents a major public health concern. Despite having been previously identified as a major research priority, the necessary clinical trials have fallen short, billions of dollars have been spent, and little progress has been made in drug development during the last decade [2]. The brains of patients with Alzheimer's disease are classically characterized by two hallmark features, beta-amyloid (A $\beta)$-containing plaques and neurofibrillary tangles, which are composed of hyperphosphorylated forms of the microtubule-associated protein tau [3]. However, there is now growing evidence that several infectious agents are also suspected of contributing to AD, notably through their interactions with $\mathrm{A} \beta$ plaques through inflammatory processes.

The 'germ theory of disease' dates back to the 1800s [4], but there is more recent evidence that certain infectious agents may be contributing factors to the pathogenesis of AD. For instance, herpes simplex virus 1 (HSV1)-carrying individuals have an increased risk of later developing AD [5]. Further, antiviral medications against the herpes virus have been associated with a decreased risk of developing dementia [6].

There are now several drugs that have been approved for the treatment of infectious diseases by the United States Food and Drug Administration (FDA) which also have been associated with reductions in AD risk or disease progression when used off-label. The infectious agents most often associated with AD are herpes viruses, spirochetes, Chlamydia pneumoniae, Porphyromonas gingivalis, mycobacteria, and toxoplasma parasites. Here, I present evidence for the relationships between each of these infectious diseases and AD, as well as illustrate the potential use for antiviral and antimicrobial agents for its therapy. I further assert that it is now time to start clinical trials of existing federally approved drugs against each of the top six infectious suspects to determine if such treatments can delay, halt, or reverse the progression of AD. 


\section{Infectious Agents-Six Known Suspects for Alzheimer's Disease}

\subsection{Herpes Viruses}

There are a series of epidemiological studies, as well as genetic research, that have implicated herpes viruses (most notably HSV1) in AD. Albeit primarily correlational, the evidence for this association in human populations is compelling. Individuals who carry HSV1 are at an increased risk of developing AD later in life [7]. This is particularly true for those who carry both HSV1 and the type four allele of the apolipoprotein E gene (APOEE4) [8]. This allele has a longstanding association with AD risk in human populations [9]. One report demonstrated that HSV1 infection of cell cultures upregulated microRNA146a, which is associated with altered immune responses; however, treatment with the antiviral agent acyclovir attenuated the neuroinfectious actions of HSV1 [10]. Altered innate immune responses are considered by many to be associated with both the APOE- $\varepsilon 4$ gene and AD progression [11,12]. Importantly, animal research has shown a causal role for the APOE- $\varepsilon 4$ genetic variant in the accumulation of $A \beta$ protein [13].

$\mathrm{A} \beta$ protein deposits in the brain (also known as plaques) are a hallmark feature of $\mathrm{AD}$ [13]. In fact, some researchers have postulated that $A \beta$ is produced in response to HSV1 viral infection and is actually an antimicrobial peptide $[14,15]$. Research has also shown that $\mathrm{A} \beta$ tends to accumulate in brain cells (both using in vitro and in vivo methodology) that have specifically been infected with HSV1 [16,17]. Additionally, in post-mortem AD brain tissue, a significant proportion of HSV1 DNA was associated with A $\beta$ plaques [18]. Moreover, in one study, when the antiviral drugs acyclovir, penciclovir, and foscarnet were used to treat HSV1-infected cell cultures, A $\beta$ protein levels decreased [19]. Taken together, the above data suggest that antivirals which have been effective for the treatment of HSV1 could potentially impact AD progression, primary through interactions with $\mathrm{A} \beta$ protein accumulation and the resultant plaques that form.

\subsection{Spirochetes}

Spirochetes is a group of spiral bacteria that causes infections such as syphilis and Lyme disease. One of the infectious agents from this group most strongly associated with AD is Treponema pallidum (T. pallidum). T. pallidum is the microbe responsible for syphilis, and has been linked to dementia, shrinkage of the brain's cortex, and deposition of $A \beta$ protein [20]. Periodontal disease, which is characterized by the presence of various species from the genus Treponema (T. pectinovorum, T. amylovorum, T. lecithinolyticum, T. maltophilum, T. medium, and T. socranskii) has also been associated with AD in epidemiological work [21]. Other spirochetes have been linked to AD as well. For instance, in 1987, MacDonald and Miranda [22] first noted the presence of Lyme disease-causing Borrelia burgdorferi ( $B$. burgdorferi) in the brain of an AD patient. Later, it was shown that B. burgdorferi causes in vitro glial and neuronal cell cultures to accumulate $A \beta$ in a manner similar to that observed in AD patients [23]. However, it is important to note that some of these links may indeed be solely correlational.

One theory on the role of these bacteria in AD is that spirochetes make biofilms that activate the innate immune system [24]. When toll-like receptor 2 responds to the production of these bacterial biofilms, inflammatory cytokines such as tumor necrosis factoralpha (TNF- $\alpha$ ) and the transcription factor nuclear factor kappa B (NF- $\mathrm{B}$ ) are activated. These factors cause not only tissue damage, but also produce $A \beta$. This same researcher also postulates that treatment with a bactericidal antibiotic (such as penicillin) with a concurrent biofilm disperser (such as rifampin) may help halt AD progression, but only if given early in the course of the disease. In fact, Allen [24] suggests a very specific treatment regimen for early dementia that consists of penicillin (administered intramuscularly) at $1.2 \mathrm{mu}$ biweekly for 3 doses, probenecid at $500 \mathrm{mg}$ bid (to increase the concentration of penicillin), citalopram at $20 \mathrm{mg}$ daily, and rifampin at $500 \mathrm{mg}$ bid.

Preliminary clinical studies indeed support Allen's general idea. For instance, in a placebo-controlled clinical study conducted in Canada, oral daily doses of doxycycline (200 mg) and rifampin (300 mg for 3 months) were administered to over a hundred 
patients with probable $\mathrm{AD}$, and significant therapeutic benefits were noted in cognition and dysfunctional behaviors [25]. Drugs not called "antibiotics", but which have antibiotic-like action, can also be worthwhile for investigation. For instance, the anti-alcoholism drug disulfiram (which works, at least in part, to break down biofilms) has been recently used for the treatment of Lyme disease. Expanding these clinical trials to include AD is a logical next step [26].

\subsection{Chlamydia Pneumoniae}

Similar evidence has been observed in studies of Chlamydia pneumoniae (C. pneumoniae)-a bacteria known for commonly causing both upper and lower respiratory infections. This bacteria has been found in post-mortem brain tissue of AD patients $[27,28]$. Importantly, research has demonstrated a causal role of $C$. pneumoniae in pathological features of $\mathrm{AD}$. Specifically, in one study C. pneumoniae was delivered intranasally to wild-type laboratory mice, and $A \beta$ plaques subsequently formed as a result [29].

Treatments for $C$. pneumoniae may also be useful in the fight against AD. The antibiotic rifampin has been shown to not only treat the infections caused by C. pneumoniae, but it also prevents accumulation of $A \beta$ in cell cultures [30]. Similarly, another antibiotic agent against $C$. pneumoniae, tetracycline, has been shown in vitro to both inhibit $\mathrm{A} \beta$ deposit formation and disassemble the pre-formed fibrils that are also associated with $\mathrm{AD}$ [31]. It is noteworthy that again we see this relationship between an infectious agent and $A \beta$ which can be ameliorated through the use of drugs that target the microbial suspect.

\subsection{Porphyromonas Gingivalis}

Porphyromonas gingivalis (P. gingivalis) is another periodontal disease-causing oral bacterium that is linked to cognitive impairment, dementia, and $\mathrm{AD}[32,33]$. One genomewide association study (GWAS) has demonstrated that genes of the P. gingivalis interactome were significantly enriched in genes that are related to cognitive disorders, $\mathrm{AD}$, and dementia [34].

Periodontal disease has also been linked to higher $\mathrm{A} \beta$ load in cognitively normal, aged individuals who do not have AD [35]. Further, in one study, oral P. gingivalis infections in mice increased production of $A \beta$ within the brain. In this same study, small-molecule inhibitors targeting gingipains were developed and subsequently used. Gingipain inhibition both reduced $\mathrm{P}$. gingivalis infection, $\mathrm{A} \beta$ production, and TNF- $\alpha$ expression, and rescued hippocampal cells, suggesting that gingipain inhibitors could potentially be used in the treatment of AD [36]. This group's small-molecule inhibitor of gingipains (COR388) has already passed Phase 1 clinical trials and is now running a Phase $2 / 3$ study to determine if this drug can improve cognition in people with AD [37]. However, more studies and clinical trials like these are necessary.

\subsection{Toxoplasma}

Toxoplasma (or toxoplasmosis) is a disease that results from infection with the Toxoplasma gondii (T. gondii) parasite. This parasite can inhabit the human body for a long time, sometimes with no effects, but an immune system challenge can trigger toxoplasma illness and serious health problems [38]. One meta-analysis demonstrates that T. gondii is, in fact, another external risk factor for the development of $\mathrm{AD}$ [39]. Rodent research has shown that $T$. gondii induced signs of AD in mice, including anxiety-like behaviors, altered social recognition memory, and deficits in spatial memory [40]. Another study found that $T$. gondii infection potentiated memory impairments via a neuroinflammation pathway in a BALB/c mouse model of AD [41]. This particular mouse model of AD-like impairment was created by injecting $A \beta$ into the hippocampus. Thus, again we see evidence that infectious agents may instigate $\mathrm{AD}$ through their interactions with both inflammation and $\mathrm{A} \beta$ plaques.

In one hallmark study, anti-parasitic drug (nitazoxanide) treatment improved learning and memory impairments in a mouse model of AD that genetically targets the amyloid precursor protein [42]. However, while this association between the T. gondii parasitic 
infection, $\mathrm{AD}$, and amyloid proteins appears to be scientifically supported at a basic science and pre-clinical level, there has been little clinical research into the use of antiparasitic drugs in the treatment of AD. This may be partially due to some generic antiparasitic agents (notably, pyrimethamine) being inaccessible to researchers for many years due to the high costs imposed by pharmaceutical companies [43].

\subsection{Mycobacteria}

Finally, we have mycobacteria. They represent an entire genus of bacteria (nearly 200 species), many of which have been known to cause infectious diseases such as tuberculosis and leprosy in humans. These bacteria are also strongly associated with AD. In fact, pharmaceutical agents against mycobacteria have been shown to decrease AD risk. In one study of aged patients treated with rifampicin for mycobacterial infections, this antibiotic was found to decrease the chances of later developing AD, but only if the drug was taken at a dose of at least $450 \mathrm{mg}$ daily for one year [44]. In another recent study, Bacillus Calmette-Guérin, which is a vaccine against tuberculosis, was found to decrease the incidence of $\mathrm{AD}$ development in a sample of people who had it instilled into their bladders as a treatment for bladder cancer. The researchers believed that these results would generalize to larger populations [45]. Notably, the mycobacterium responsible for tuberculosis forms amyloid-like fibrils both in vitro cell cultures as well as in vivo [46].

While there have been conflicting reports on the interaction between the mycobacteria responsible for leprosy and $\mathrm{AD}$, an interesting new paper may shed light on this relationship. Specifically, researchers in Korea administered the antibiotic/anti-inflammatory drug known as dapsone at $100 \mathrm{mg}$ once a day from 2010 to 2015 for the treatment of mild cognitive impairment (MCI). However, because of drug production changes in Korea, the dapsone regimen was discontinued, and the patient who served as the case example subsequently developed AD. Then, in 2018, the physicians were able to restart the dapsone regimen and the patient reverted from $\mathrm{AD}$ back to $\mathrm{MCI}$ after one year of treatment. The researchers attributed the positive effects of this drug to its anti-inflammatory actions [47].

\section{Conclusions}

In short, there is compelling evidence to suggest that select viruses and microbes are linked to the development and progression of AD. Despite this, there is only limited research to suggest that the treatments against such infectious agents have the potential to halt, delay, or reverse $\mathrm{AD}$. How these drugs affect $\mathrm{A} \beta$ plaque deposits is likely a major contributing factor to their therapeutic potential. Interestingly, $A \beta$ itself may in fact be an antimicrobial peptide in the immune system [48]. Inflammation is another important contributor to $\mathrm{AD}$; therefore, anti-inflammatory drugs may also prove to be useful for the treatment of this disorder [49].

It is likely that one of the primary route by which these microorganisms impact $A \beta$ and $\mathrm{AD}$ are via inflammation processes, notably inflammatory cytokines in the brain. The microbiome has also been shown to play a critical role in the development of dementias recently. In fact, it was recently shown that pathological features of Parkinson's disease may start via protein accumulation starts in the gastrointestinal system and ascends to the brain via vagal fibers [50]. The microbiome of patients with $\mathrm{AD}$ is also significantly altered compared to non-AD control subjects [51]. However, more research is needed on this topic in how it relates to the microorganisms discussed herein and AD.

Despite this growing body of literature to support infectious agents' participation in $\mathrm{AD}$, few clinical trials are currently underway to test this hypothesis. As mentioned previously, the gingipain inhibitor known as COR388 is currently in Phase 2/3 clinical trials [37]. Another drug currently in Phase 2 clinical testing in the United State is the antiviral valacyclovir. In this 78-week trial, patients are being given valacyclovir at an oral dose of $4 \mathrm{~g}$ daily (after titration) in order to slow cognitive decline [52].

There are many FDA-approved drugs for the treatment of the six known infectious suspects of AD. New drug development takes much time and money, but with these 
already-approved compounds the clinical trial process can be quickly started. Thus, with economies of time and cost, we could potentially find a quicker way to halt, delay, or even reverse $\mathrm{AD}$.

Funding: No external funding was received for this review.

Conflicts of Interest: Dr. Norins is founder and principal of Alzheimer's Germ Quest, which is a Florida-based charity to encourage deeper investigation of the possible role of microbes in Alzheimer's disease. It is independent and self-funded, and does not sell anything or seek or accept outside donations. So far it has donated microbe-related grant funds to Duke Medical School, Infectious Diseases Society of America, Hebrew University of Jerusalem, Edinburgh University, Manchester University, Umea University, University of Chicago, and University of Wisconsin. It has no "commercial" activities, and no interactions with the drug industry.

\section{References}

1. Association, A. 2018 Alzheimer's disease facts and figures. Alzheimer's Dement. 2018, 14, 367-429.

2. Mehta, D.; Jackson, R.; Paul, G.; Shi, J.; Sabbagh, M. Why do trials for Alzheimer's disease drugs keep failing? A discontinued drug perspective for 2010-2015. Expert Opin. Investig. Drugs 2017, 26, 735-739. [CrossRef]

3. Ittner, L.M.; Götz, J. Amyloid- $\beta$ and tau-A toxic pas de deux in Alzheimer's disease. Nat. Rev. Neurosci. 2011, 12, 67-72. [CrossRef] [PubMed]

4. Pasteur, L.; Joubert, J.; Chamberland, C. The germ theory of disease. CR Hebd Seances Acad. Sci. 1878, 86, 1037-1052.

5. Lövheim, H.; Gilthorpe, J.; Johansson, A.; Eriksson, S.; Hallmans, G.; Elgh, F. Herpes simplex infection and the risk of Alzheimer's disease: A nested case-control study. Alzheimer's Dement. 2015, 11, 587-592. [CrossRef]

6. Bae, S.; Yoon, W.; Choi, S.W.; Yun, S.; Kim, S.; Kim, S.Y. Antiviral therapy reduces the risk of dementia in patients with herpes zoster: A propensity score-matched analysis: Epidemiology/Risk and protective factors in MCI and dementia. Alzheimer's Dement. 2020, 16, e041698. [CrossRef]

7. Lövheim, H.; Gilthorpe, J.; Adolfsson, R.; Nilsson, L.-G.; Elgh, F. Reactivated herpes simplex infection increases the risk of Alzheimer's disease. Alzheimer's Dement. 2015, 11, 593-599. [CrossRef] [PubMed]

8. Itzhaki, R.F.; Lin, W.-R.; Shang, D.; Wilcock, G.K.; Faragher, B.; Jamieson, G.A. Herpes simplex virus type 1 in brain and risk of Alzheimer's disease. Lancet 1997, 349, 241-244. [CrossRef]

9. Michaelson, D.M. APOE $\varepsilon 4$ : The most prevalent yet understudied risk factor for Alzheimer's disease. Alzheimer's Dement. 2014, 10, 861-868. [CrossRef] [PubMed]

10. Lukiw, W.J.; Cui, J.G.; Li, Y.Y.; Bhattacharjee, P.S.; Corkern, M.; Clement, C.; Kammerman, E.M.; Ball, M.J.; Zhao, Y.; Hill, J.M. Acyclovir and A $\beta 42$ peptide attenuates HSV-1-induced miRNA-146a levels in human brain cells. Neuroreport 2010, $21,922$. [CrossRef]

11. Keene, C.D.; Cudaback, E.; Li, X.; Montine, K.S.; Montine, T.J. Apolipoprotein E isoforms and regulation of the innate immune response in brain of patients with Alzheimer's disease. Curr. Opin. Neurobiol. 2011, 21, 920-928. [CrossRef] [PubMed]

12. Sekar, S.; McDonald, J.; Cuyugan, L.; Aldrich, J.; Kurdoglu, A.; Adkins, J.; Serrano, G.; Beach, T.G.; Craig, D.W.; Valla, J. Alzheimer's disease is associated with altered expression of genes involved in immune response and mitochondrial processes in astrocytes. Neurobiol. Aging 2015, 36, 583-591. [CrossRef] [PubMed]

13. Youmans, K.L.; Tai, L.M.; Nwabuisi-Heath, E.; Jungbauer, L.; Kanekiyo, T.; Gan, M.; Kim, J.; Eimer, W.A.; Estus, S.; Rebeck, G.W. APOE4-specific changes in A $\beta$ accumulation in a new transgenic mouse model of Alzheimer disease. J. Biol. Chem. 2012, 287, 41774-41786. [PubMed]

14. Sadigh-Eteghad, S.; Sabermarouf, B.; Majdi, A.; Talebi, M.; Farhoudi, M.; Mahmoudi, J. Amyloid-beta: A crucial factor in Alzheimer's disease. Med. Princ. Pract. 2015, 24, 1-10. [CrossRef] [PubMed]

15. Soscia, S.J.; Kirby, J.E.; Washicosky, K.J.; Tucker, S.M.; Ingelsson, M.; Hyman, B.; Burton, M.A.; Goldstein, L.E.; Duong, S.; Tanzi, R.E.; et al. The Alzheimer's disease-associated amyloid $\beta$-protein is an antimicrobial peptide. PLoS ONE 2010, 5. [CrossRef]

16. Santana, S.; Recuero, M.; Bullido, M.J.; Valdivieso, F.; Aldudo, J. Herpes simplex virus type I induces the accumulation of intracellular $\beta$-amyloid in autophagic compartments and the inhibition of the non-amyloidogenic pathway in human neuroblastoma cells. Neurobiol. Aging 2012, 33, 430.e19-430.e33. [CrossRef] [PubMed]

17. Li Puma, D.D.; Piacentini, R.; Leone, L.; Gironi, K.; Marcocci, M.E.; De Chiara, G.; Palamara, A.T.; Grassi, C. Herpes simplex virus Type-1 infection impairs adult hippocampal neurogenesis via amyloid- $\beta$ protein accumulation. Stem. Cells 2019, 37, 1467-1480. [CrossRef]

18. Wozniak, M.A.; Mee, A.P.; Itzhaki, R.F. Herpes simplex virus type 1 DNA is located within Alzheimer's disease amyloid plaques. J. Pathol. A J. Pathol. Soc. Gt. Br. Irel. 2009, 217, 131-138. [CrossRef] [PubMed]

19. Wozniak, M.A.; Frost, A.L.; Preston, C.M.; Itzhaki, R.F. Antivirals reduce the formation of key Alzheimer's disease molecules in cell cultures acutely infected with herpes simplex virus type 1. PLoS ONE 2011, 6, e25152.

20. Miklossy, J. Chronic inflammation and amyloidogenesis in Alzheimer's disease-Role of spirochetes 1. J. Alzheimer's Dis. 2008, 13, 381-391. [CrossRef] [PubMed] 
21. Lee, Y.; Hu, H.; Huang, L.; Chou, P.; Chu, D. Periodontal disease associated with higher risk of dementia: Population-based cohort study in Taiwan. J. Am. Geriatr. Soc. 2017, 65, 1975-1980. [CrossRef] [PubMed]

22. MacDonald, A.B.; Miranda, J.M. Concurrent neocortical borreliosis and Alzheimer's disease. Hum. Pathol. 1987, 18, 759. [CrossRef]

23. Miklossy, J.; Kis, A.; Radenovic, A.; Miller, L.; Forro, L.; Martins, R.; Reiss, K.; Darbinian, N.; Darekar, P.; Mihaly, L. Beta-amyloid deposition and Alzheimer's type changes induced by Borrelia spirochetes. Neurobiol. Aging 2006, 27, 228-236. [CrossRef]

24. Allen, H.B. Alzheimer's disease: Assessing the role of spirochetes, biofilms, the immune system, and amyloid- $\beta$ with regard to potential treatment and prevention. J. Alzheimer's Dis. 2016, 53, 1271-1276. [CrossRef] [PubMed]

25. Loeb, M.B.; Molloy, D.W.; Smieja, M.; Standish, T.; Goldsmith, C.H.; Mahony, J.; Smith, S.; Borrie, M.; Decoteau, E.; Davidson, W. A randomized, controlled trial of doxycycline and rifampin for patients with Alzheimer's disease. J. Am. Geriatr. Soc. 2004, 52, 381-387. [CrossRef] [PubMed]

26. Gao, J.; Gong, Z.; Montesano, D.; Glazer, E.; Liegner, K. "Repurposing” disulfiram in the treatment of lyme disease and babesiosis: Retrospective review of first 3 years' experience in one medical practice. Antibiotics 2020, 9, 868. [CrossRef] [PubMed]

27. Balin, B.J.; Gérard, H.C.; Arking, E.J.; Appelt, D.M.; Branigan, P.J.; Abrams, J.T.; Whittum-Hudson, J.A.; Hudson, A.P. Identification and localization of Chlamydia pneumoniae in the Alzheimer's brain. Med. Microbiol. Immunol. 1998, 187, 23-42. [CrossRef] [PubMed]

28. Hammond, C.J.; Hallock, L.R.; Howanski, R.J.; Appelt, D.M.; Little, C.S.; Balin, B.J. Immunohistological detection of Chlamydia pneumoniae in the Alzheimer's disease brain. BMC Neurosci. 2010, 11, 121. [CrossRef] [PubMed]

29. Little, C.S.; Hammond, C.J.; MacIntyre, A.; Balin, B.J.; Appelt, D.M. Chlamydia pneumoniae induces Alzheimer-like amyloid plaques in brains of BALB/c mice. Neurobiol. Aging 2004, 25, 419-429. [CrossRef]

30. Tomiyama, T.; Asano, S.; Suwa, Y.; Morita, T.; Kataoka, K.; Mori, H.; Endo, N. Rifampicin prevents the aggregation and neurotoxicity of amyloid $\beta$ protein in vitro. Biochem. Biophys. Res. Commun. 1994, 204, 76-83. [CrossRef] [PubMed]

31. Forloni, G.; Colombo, L.; Girola, L.; Tagliavini, F.; Salmona, M. Anti-amyloidogenic activity of tetracyclines: Studies in vitro. FEBS Lett. 2001, 487, 404-407. [CrossRef]

32. Noble, J.M.; Borrell, L.N.; Papapanou, P.N.; Elkind, M.S.V.; Scarmeas, N.; Wright, C.B. Periodontitis is associated with cognitive impairment among older adults: Analysis of NHANES-III. J. Neurol. Neurosurg. Psychiatry 2009, 80, 1206-1211. [CrossRef]

33. Ide, M.; Harris, M.; Stevens, A.; Sussams, R.; Hopkins, V.; Culliford, D.; Fuller, J.; Ibbett, P.; Raybould, R.; Thomas, R. Periodontitis and cognitive decline in Alzheimer's disease. PLoS ONE 2016, 11, e0151081. [CrossRef]

34. Carter, C.J.; France, J.; Crean, S.; Singhrao, S.K. The Porphyromonas gingivalis/host interactome shows enrichment in GWASdb genes related to Alzheimer's disease, diabetes and cardiovascular diseases. Front. Aging Neurosci. 2017, 9, 408.

35. Kamer, A.R.; Pirraglia, E.; Tsui, W.; Rusinek, H.; Vallabhajosula, S.; Mosconi, L.; Yi, L.; McHugh, P.; Craig, R.G.; Svetcov, S. Periodontal disease associates with higher brain amyloid load in normal elderly. Neurobiol. Aging 2015, 36, 627-633. [PubMed]

36. Dominy, S.S.; Lynch, C.; Ermini, F.; Benedyk, M.; Marczyk, A.; Konradi, A.; Nguyen, M.; Haditsch, U.; Raha, D.; Griffin, C. Porphyromonas gingivalis in Alzheimer's disease brains: Evidence for disease causation and treatment with small-molecule inhibitors. Sci. Adv. 2019, 5, eaau3333. [CrossRef] [PubMed]

37. Detke, M.; Lynch, C.; Holsinger, L.; Kapur, S.; Hennings, D.; Raha, D.; Broce, S.; Nguyen, M.; Ermini, F.; Haditsch, U. COR388 for the treatment of Alzheimer's disease. Neurology 2020, 94 (Suppl. 15), 4098.

38. Innes, E.A. A brief history and overview of Toxoplasma gondii. Zoonoses Public Health 2010, 57, 1-7. [CrossRef] [PubMed]

39. Chegeni, T.N.; Sarvi, S.; Moosazadeh, M.; Sharif, M.; Aghayan, S.A.; Amouei, A.; Hosseininejad, Z.; Daryani, A. Is Toxoplasma gondii a potential risk factor for Alzheimer's disease? A systematic review and meta-analysis. Microb. Pathog. $2019,137,103751$. [CrossRef]

40. Torres, L.; Robinson, S.-A.; Kim, D.-G.; Yan, A.; Cleland, T.A.; Bynoe, M.S. Toxoplasma gondii alters NMDAR signaling and induces signs of Alzheimer's disease in wild-type, C57BL/ 6 mice. J. Neuroinflamm. 2018, 15, 57.

41. Mahmoudvand, H.; Sheibani, V.; Shojaee, S.; Mirbadie, S.R.; Keshavarz, H.; Esmaeelpour, K.; Keyhani, A.R.; Ziaali, N. Toxoplasma gondii infection potentiates cognitive impairments of Alzheimer's disease in the BALB/c mice. J. Parasitol. 2016, 102, 629-635. [CrossRef]

42. Fan, L.; Qiu, X.; Zhu, Z.; Lv, J.; Lu, J.; Mao, F.; Zhu, J.; Wang, J.; Guan, X.; Chen, J. Nitazoxanide, an anti-parasitic drug, efficiently ameliorates learning and memory impairments in AD model mice. Acta Pharmacol. Sin. 2019, 40, 1279-1291. [CrossRef] [PubMed]

43. Tallapragada, N.P. Off-patent drugs at brand-name prices: A puzzle for policymakers. J. Law Biosci. 2016, 3, 238-247. [CrossRef] [PubMed]

44. Iizuka, T.; Morimoto, K.; Sasaki, Y.; Kameyama, M.; Kurashima, A.; Hayasaka, K.; Ogata, H.; Goto, H. Preventive effect of rifampicin on Alzheimer disease needs at least $450 \mathrm{mg}$ daily for 1 year: An FDG-PET follow-up study. Dement. Geriatr. Cogn. Dis. Extra 2017, 7, 204-214. [CrossRef] [PubMed]

45. Gofrit, O.N.; Klein, B.Y.; Cohen, I.R.; Ben-Hur, T.; Greenblatt, C.L.; Bercovier, H. Bacillus Calmette-Guérin (BCG) therapy lowers the incidence of Alzheimer's disease in bladder cancer patients. PLoS ONE 2019, 14, e0224433. [CrossRef] [PubMed]

46. Kaur, G.; Kaundal, S.; Kapoor, S.; Grimes, J.M.; Huiskonen, J.T.; Thakur, K.G. Mycobacterium tuberculosis CarD, an essential global transcriptional regulator forms amyloid-like fibrils. Sci. Rep. 2018, 8, 1-13.

47. Lee, J.; Choi, S.; Lee, C.J.; Oh, S. Recovery of Dementia Syndrome following Treatment of Brain Inflammation. Dement. Geriatr. Cogn. Dis. Extra 2020, 10, 1-12. [CrossRef] 
48. Spitzer, P.; Condic, M.; Herrmann, M.; Oberstein, T.J.; Scharin-Mehlmann, M.; Gilbert, D.F.; Friedrich, O.; Grömer, T.; Kornhuber, J.; Lang, R. Amyloidogenic amyloid- $\beta$-peptide variants induce microbial agglutination and exert antimicrobial activity. Sci. Rep. 2016, 6, 32228. [CrossRef]

49. Wyss-Coray, T.; Rogers, J. Inflammation in Alzheimer disease-A brief review of the basic science and clinical literature. Cold Spring Harb. Perspect. Med. 2012, 2, a006346. [CrossRef] [PubMed]

50. Challis, C.; Hori, A.; Sampson, T.R.; Yoo, B.B.; Challis, R.C.; Hamilton, A.M.; Mazmanian, S.K.; Volpicelli-Daley, L.A.; Gradinaru, V. Gut-seeded $\alpha$-synuclein fibrils promote gut dysfunction and brain pathology specifically in aged mice. Nat. Neurosci. 2020, 23, 327-336. [CrossRef] [PubMed]

51. Vogt, N.M.; Kerby, R.L.; Dill-McFarland, K.A.; Harding, S.J.; Merluzzi, A.P.; Johnson, S.C.; Carlsson, C.M.; Asthana, S.; Zetterberg, H.; Blennow, K.; et al. Gut microbiome alterations in Alzheimer's disease. Sci. Rep. 2017, 7, 1-11.

52. Devanand, D.P.; Andrews, H.; Kreisl, W.C.; Razlighi, Q.; Gershon, A.; Stern, Y.; Mintz, A.; Wisniewski, T.; Acosta, E.; Pollina, J. Antiviral therapy: Valacyclovir treatment of Alzheimer's Disease (VALAD) Trial: Protocol for a randomised, double-blind, placebo-controlled, treatment trial. BMJ Open 2020, 10. [CrossRef] [PubMed] 